УДК 633.11:620.21:502/504(470.56)

(C) 2016

Гавриленко О. С., кандидат ветеринарних наук, Хоміцька О. А., завідувач сектору мікробіологічних випробувань, Загорулько О. В., старший науковий співробітник

Український державний науково-дослідний інститут «Ресурс»

\title{
ОЦІКАА ВПЛИВУ МІКРОБІОЛОГІЧНИХ ПРОЦЕСІВ ПІД ЧАС ЗБЕРІГАННЯ ЗЕРНА ЯРОЇ ПШЕНИЦІ
}

\section{Рецензент - доктор ветеринарних наук В. М. Муковоз}

Вивчено вплив комплексного препарату зі складовими мікроелементного походження на бактерії та культури грибів, виділені з зерна ярої пшениці ДП Новотройцького елеватора Київсккої області в період зберігання. Встановлено ефективність фунгіцицної діï препарату, до складу якого входять мікроелементи срібло та мідь у формі органічних солей карбонових кислот, отриманих за допомогою нанотехнологій. Представлено результати досліджень видового складу збудників хвороб зерна озимої пшениці.

Ключові слова: зерно, мікроелементи, ступінь зараження, спороутворюючі мікроорганізми, фунгіцицна дія.

Постановка проблеми. Зерно і продукти його переробки $\epsilon$ основним джерелом харчування людини і кормом для тварин. Тому проблема мікробіологічного забруднення зерна являється одним $з$ головних чинників, що визначають здоров'я населення. У зв'язку з цим, велика увага приділяється необхідності вивчення методів захисту врожаю насіння від шкідників та хвороб у випадку тривалого зберігання, підвищення показників якості зерна, дослідження грибів, що вражають насіння в період зберігання та застосування хімічних та біологічних засобів для обробки зерна [1-3].

Аналіз основних досліджень і публікацій, у яких започатковано розв'язання проблеми. Посіви зернових культур в Україні займають близько 14,5 млн га [4]. Зерно складається, в основному, з крохмалю, протеїну і незначної частини жиру, що є ідеальним живильним середовищем для розвитку мікроорганізмів. Тільки один грам зернової маси містить від декількох сотень до декількох тисяч мікроорганізмів [4]. Розвиток цих мікроорганізмів є однією 3 можливих причин зниження якості зерна пшениці та інших зернових культур під час зберігання. Залежно від умов зберігання зернової маси зміни в чисельному та видовому складі іiі мікрофлори можуть носити різний характер [5]. Оскільки мікробне забруднення присутнє на всіх етапах життєвого циклу зерна - в полі, під час збирання, транспортування, зберігання та переробці, - інтенсивність зараженості бактеріями може бути досить велика [6].

Через насіння може передаватися до $60 \%$ збудників хвороб бактеріального і грибного походження, що, врешті-решт, позначається на врожаї і на їхній якості. Значення економічних збитків, які завдають бактеріальні та вірусні інфекції, плісеневі гриби важко переоцінити, оскільки врожай зерна інфікованих рослин знижується в середньому на 35-65\%, а втрати врожаю можуть досягати $90 \%[5,6]$. Рослини уражаються багатьма патогенними та споровими мікроорганізмами. Це бактерії групи Enterobacteriaceae та плісеневі гриби роду Fusarium (F. nivale, F. culmorum, F. graminearum, F. avenaceum), Tilletia (T. caries та T. controversa), Cladosporium (C. herbarum herbarum), Claviceps (C. purpurea), бактеріï роду Bacillus, Pénicillium spp., Epicoccum spp., Trichothecium spp. i т. д. [4-6]. Ураження такими мікроорганізмами перешкоджає нормальному формуванню врожаю, а спори цих бактерій, потрапляючи в організм людини, здатні викликати досить серйозні порушення функціонування імунної системи, шлунково-кишкового тракту, органів дихання, нервової системи $[5,7]$.

Сезонність виробництва зерна, з одного боку, і споживання його протягом усього року, з іншого, вимагають організувати тривале зберігання великих мас зерна в елеваторах Держрезерву України. Дослідження на бактеріальні інфекції зерна ярої пшениці є одним з елементів насіннєвого контролю та має важливе значення. Це дає можливість оцінити ступінь зараженості й ухвалити правильне рішення щодо проведення обробки зерен пшениці.

Актуальність встановлення мікологічної характеристики зерна основної продовольчої культури пшениці ярої та вибору препарату для обробки зерна з метою зменшення ступеню зараженості споровими бактеріями не викликає сумнівів.

Для захисту озимої пшениці та інших сільськогосподарських культур від борошнисто-росяних 


\section{СІЛЬСЬКЕ ГОСПОДАРСТВО. РОСЛИННИЦТВО}

грибів, іржі, гнилей, септоріозу та інших плямистостей використовують високоефективний багатофункціональний системний фунгіцид - «Тебуконазол». Широкий діапазон системної дії ставить препарат на одне 3 перших місць в асортименті протруйників. Він швидко проникає в рослину через асиміляційні частини, пригнічує біосинтез ергостеролу, порушуючи процеси метаболізму та утворення клітинних мембран, що призводить до загибелі патогенів. Однак цей препарат високотоксичний і відноситься до 2-го класу небезпеки $[8,9]$.

Дані характеристики «Тебуконазолу» підтверджують необхідність пошуку шляхів зменшення його токсичності та еконебезпеки в разі збереження специфічної активності. Досліди багатьох вітчизняних та європейських вчених неодноразово доводили, що використання в рослинництві фунгіцидів, отриманих за нанотехнологіями, забезпечує значне підвищення імунітету у рослин $\mathrm{i}$ значно збільшує врожайність продовольчих культур [8].

Доведено, що біологічну активність препарату на основі «Тебуконазолу» можна підвищити, створивши більш ефективну форму, здатну забезпечити найкращий контакт препарату 3 рослиною за рахунок більш ефективного проникнення фунгіциду в кутикулу зернини. До таких форм можна віднести композиції у вигляді рідин, що характеризуються включенням в їхній склад діючих речовин нанорозміру і забезпечують швидке та ефективне проникнення в рослину [8]. Мікроелементи срібло та мідь у формі органічних солей карбонових кислот, що отримують методами нанотехнологій, виявляють виражені біоцидні властивості та відносяться до 4го класу малонебезпечних речовин. Характерним для даних речовин $є$ висока біологічна активність у малих дозах і сумісність з іншими препаратами [10].

Мета досліджень - вивчити вплив комплексного препарату на основі «Тебуконазолу», що містить мікроелементи срібла та міді на бактерії і спори грибів, виділені з зерна ярої пшениці ДП Новотроїцького елеватора, с. Чкалове, Київської області.

\section{Завдання дослідження:}

1. Провести дослідження загальної кількості бактерій та плісеневих грибів зразків пшениці трьох зразків зерна ярої пшениці до і після обробки дослідним комплексним розчином згідно 3 ГОСТ 10444.15 - 94, ДСТУ ISO 4833:2006, ГОСТ 26972 - 86, ГОСТ 10444.12-2013, ДСТУ ISO 7954:2006 та ГОСТ 29184 - 91 [12-17].

2. Провести дослідження зараженості мікроміцетами зразків пшениці ярої до і після обробки дослідним комплексним розчином згідно 3 ДСТУ 4138-2002, ДСТУ 3768:2004 та ГОСТ 13496.11-74 [18-20].

Матеріали і методи досліджень. Об'єктами дослідження були: комплексний дослідний розчин, що містить 1,25 мл «Тебуконазолу», 0,05 мг $\mathrm{Ag}$ та 0,05 мг $\mathrm{Cu}$ на 100 мл води. Мікроелементи срібла та міді у формі органічних солей карбонових кислот, що отримують методами нанотехнологій. Зерно ярої пшениці, що зберігається в ДП Новотроїцького елеватора, необроблене (209 т) та оброблене перед закладкою на зберігання інсектицидом «Пірігрен 50» проти шкідників зерна - комах та кліщів (1600 т). У дослідженнях використовували три зразки зерна: зразок № 1 необроблені зерна пшениці, який використовувався в якості контролю, зразок № 2 - зерна пшениці, оброблені дослідним комплексним розчином, зразок № 3 - зерна пшениці, оброблені інсектицидом «Пірігрен 50» та дослідним комплексним розчином. Експозиція обробки становила 3 години.

Дослідження проводили в секторі мікробіологічних випробовувань лабораторії досліджень хіміко-біологічних чинників УкрНДІ «Ресурс» Державного агентства резерву України. Відбирали проби згідно з ГОСТ 13586.3 [11]. Проби брали 3 різних місць. Відібрані точкові проби зерна переглядали i, переконавшись в їх однорідності, змішували (складали об'єднану пробу). 3 отриманої кількості насіння виділяли середні проби масою не менш 2 кг. Для аналізування 3 середньої проби виділяли чотири робочі проби по 100 насінин у кожній і використовували в дослідженнях.

Дослідження проводили на загальну кількість бактерій, мікроорганізми групи Enterobacteriaceae та плісеневі гриби згідно з ГОСТ 10444.15 - 94, ДСТУ ISO 4833:2006, ГОСТ 26972 - 86, ГОСТ 10444.12-2013, ДСТУ ISO 7954:2006 та ГОСТ $29184-91$ [12-17].

У роботі використовували триптон-соєвий агар (TCA) фірми «Merck» та картопляно-глюкозний агар (КГА) для визначення загальної кількості усіх бактерій та грибів, середовище Ендо для бактерій групи Enterobacteriaceae та середовища Сабуро та Чапека - для виявлення плісеневих грибів.

Зразки № 2 та № 3 зерна замочували на 3 години у співвідношенні 1:9 розчиненого фунгіциду. В якості контролю використовували розчин дистильованої стерильної води із наважкою зерна. Використовували метод обмивки насіння i центрифугування. Для вивчення антигрибкових властивостей розчинів проводили серійні розве- 


\section{СІЛЬСЬКЕ ГОСПОДАРСТВО. РОСЛИННИЦТВО}

дення та визначали ефективність дії дослідних розчинів щодо відсутності росту бактерій та пліснявих грибів. Розведення виконувалися на стерильній дистильованій воді. Посіви проводили глибинним і поверхневим методом. Підрахунок колоній здійснювали через 72 години після культивування при $37{ }^{\circ} \mathrm{C}$ для бактерій та через 5 діб після термостатування при температурі $25 \pm 1^{\circ} \mathrm{C}$ для пліснявих грибів. Оцінка дії розчинів проводилася методом підрахунку кількості всіх колоній, які виросли на поживних середовищах в КУО/см² (колонієутворювальних одиниць) із даних розведень.

Паралельно проводили дослідження зерна на зараженість спорами та міцелієм Alternaria spp., Septoria spp., Penicillium spp., Cladosporium spp. згідно з ДСТУ 4138 - 2002 [18]. Визначення фузаріозних зерен проводили згідно з ДСТУ 3768:2004 [19], спори сажкових грибів - згідно 3 ГОСТ 13496.11 [20]. Дослідження зразків проводили в 4 робочих пробах по 100 насінин у кожній.

Результати досліджень. У результаті проведених досліджень зразків № 2 та № 3, зерно яких було оброблене дослідним розчином і підсушене, та зразку зерна № 1 в якості контролю згідно 3 ДСТУ 4138 - 2002, ДСТУ 3768:2004, ГОСТ 13496.11 [18-20] висіяно певний спектр плісеневих грибів. Для ідентифікації мікроміцетів використовували атлас та керівництво по визначенню патогенних і умовно-патогенних грибів [21-23]. Результати представлені в таблиці № 1.

Загальна зараженість мікроміцетами (табл. 1) необробленого зерна пшениці зразку № 1 сягала до 54,7\%. Було висіяно гриби роду Fusarium, Alternaria, Septoria, Ustilago, Cladosporium та
Penicillium в кількостях від 2,5 до 14,3 \%. Насіння, що залишалось без ознак зараженості на середовищі КГА, становило 45,3\%. Використання дослідного фунгіцидного розчину, в склад якого входить «Тебуконазол» та мікроелементи срібла та міді, в порівнянні з контролем має свої переваги. Кількість зерен, що була без ознак зараженості, збільшилась до 82,0-82,8 \%. Загальна кількість заражених мікроміцетами зерен зменшується в другому зразку до 18,0, а в третьому - до 17,2 \%. Розчин повністю знищує збудників септоріозу, оливкової цвілі, летючої та твердої сажки. Зараженість фузаріозом зменшується в зразках № 2 та № 3 до 6,3 \% у порівнянні з результатами досліджень необроблених зерен - 10,5\%. До $4 \%$ зменшується зараженість збудниками альтернаріозу в двох зразках у порівнянні з результатами досліджень зразку № 1. На 11-11,3 \% зменшується зараженість збудниками пліснявіння - грибами Penicillium spp., що висіяно під час дослідження.

Результати досліджень загальної кількості усіх бактерій на зразках зерна в КУО в 1 г, що було проведено згідно з нормативними документами ГОСТ 10444.15 - 94, ДСТУ ISO 4833:2006, ГОСТ 26972 - 86, ГОСТ 10444.12-2013, ДСТУ ISO 7954:2006 та ГОСТ 29184 - 91 [12-17]. Результати представлені в таблиці 2.

Дослідження загальної кількості бактерій та плісеневих грибів зразків пшениці (таблиця 2) наглядно демонструють дію дослідного розчину 3 мікроелементами. Під час використання розчину кількість бактерій зменшується $310^{7}$ першого зразку до $10^{3} \mathrm{i} 10^{2}$ - в другому та третьому зразках.

\section{1. Результати досліджень зараженості мікроміцетами зразків пшениці}

\begin{tabular}{|l|c|c|c|}
\hline \multicolumn{1}{|c|}{ Мікроорганізми } & $\begin{array}{c}\text { № 1 - необроблені } \\
\text { зерна пшениці }\end{array}$ & $\begin{array}{c}\text { № 2 - зерна пшениці, } \\
\text { оброблені комплекс- } \\
\text { ним розчином }\end{array}$ & $\begin{array}{c}\text { № 3 - зерна пше- } \\
\text { ниці після нібулі- } \\
\text { зації + комплекс- } \\
\text { ний фунгіцид }\end{array}$ \\
\hline Загальна зараженість мікроміцетами, \% & 54,7 & 18,0 & 17,2 \\
\hline Фузаріоз (Fusarium spp.), \% & 10,5 & 6,3 & 6,3 \\
\hline Альтернаріоз (Alternaria spp.), \% & 12,3 & 8,5 & 8,8 \\
\hline Септоріоз (Septoria spp.), \% & 8,8 & 0 & 0 \\
\hline Сажка летюча (Ustilago spp.), \% & 2,5 & 0 & 0 \\
\hline Сажка тверда (Tilletia spp.), \% & 2,8 & 0 & 0 \\
\hline Оливкова цвіль (Cladosporium spp.), \% & 3,8 & 0 & 3,0 \\
\hline Пліснявіння (Penicillium sp.), \% & 14,3 & 3,3 & 82,8 \\
\hline $\begin{array}{l}\text { Насіння, що залишалось без ознак } \\
\text { зараженості, \% }\end{array}$ & 45,3 & 82,0 & 0 \\
\hline
\end{tabular}


СІЛЬСЬКЕ ГОСПОДАРСТВО. РОСЛИННИЦТВО

\section{2. Результати досліджень загальної кількості бактерій та плісеневих грибів зразків пщениці}

\begin{tabular}{|c|c|c|c|c|c|c|c|c|c|}
\hline \multirow{2}{*}{$\begin{array}{c}\text { № } \\
\text { П/П } \\
\end{array}$} & \multirow{2}{*}{$\begin{array}{c}\text { Зразки } \\
\text { зерна }\end{array}$} & \multirow{2}{*}{\multicolumn{2}{|c|}{$\begin{array}{c}\text { Загальна кількість, } \\
\text { КУО в } 1 \text { г }\end{array}$}} & \multicolumn{6}{|c|}{ Розведення } \\
\hline & & & & \multirow{2}{*}{$\begin{array}{c}10^{-1} \\
\begin{array}{c}\text { Суцільний } \\
\text { ріст }\end{array}\end{array}$} & \multirow{2}{*}{$\begin{array}{c}10^{-2} \\
\begin{array}{c}\text { Суцільний } \\
\text { ріст }\end{array}\end{array}$} & \multirow{2}{*}{$\begin{array}{c}10^{-3} \\
\begin{array}{c}\text { Суцільний } \\
\text { ріст }\end{array}\end{array}$} & \multirow{2}{*}{$\begin{array}{l}10^{-4} \\
1748\end{array}$} & \multirow{2}{*}{$\begin{array}{l}10^{-5} \\
260\end{array}$} & \multirow{2}{*}{$\begin{array}{r}10^{-6} \\
29\end{array}$} \\
\hline & \multirow[b]{2}{*}{ № 1} & $\begin{array}{l}\text { Загальна } \\
\text { кількість } \\
\text { бактерій }\end{array}$ & $2,7 \times 10^{7}$ & & & & & & \\
\hline & & $\begin{array}{c}\text { Загальна } \\
\text { кількість } \\
\text { плісеневих } \\
\text { грибів }\end{array}$ & $2,0 \times 10^{7}$ & $\begin{array}{l}\text { Суцільний } \\
\text { ріст }\end{array}$ & $\begin{array}{l}\text { Суцільний } \\
\text { ріст }\end{array}$ & $\begin{array}{l}\text { Суцільний } \\
\text { ріст }\end{array}$ & 1205 & 196 & 21 \\
\hline & \multirow[b]{2}{*}{ № 2} & $\begin{array}{l}\text { Загальна } \\
\text { кількість } \\
\text { бактерій } \\
\end{array}$ & $7,0 \times 10^{3}$ & 682 & 69 & 7 & 0 & 0 & 0 \\
\hline & & $\begin{array}{c}\text { Загальна } \\
\text { кількість } \\
\text { плісеневих } \\
\text { грибів }\end{array}$ & $1,4 \times 10^{3}$ & 165 & 14 & 1 & 0 & 0 & 0 \\
\hline & \multirow[b]{2}{*}{ № 3} & $\begin{array}{l}\text { Загальна } \\
\text { кількість } \\
\text { бактерій } \\
\end{array}$ & $1,8 \times 10^{3}$ & 227 & 14 & 0 & 0 & 0 & 0 \\
\hline & & $\begin{array}{c}\text { Загальна } \\
\text { кількість } \\
\text { плісеневих } \\
\text { грибів }\end{array}$ & $7,8 \times 10^{2}$ & 76 & 8 & 0 & 0 & 0 & 0 \\
\hline
\end{tabular}

Загальна кількість мікроорганізмів групи Enterobacteriaceae, що висіяно з № 1 зразку була $1,8 \times 10^{5}$. Зі зразків № 2 та № 3 кількість була меншою $-1,5 \times 10^{3}$ та $1,1 \times 10^{3}$. Вони були представлені бактеріями роду Escherichia, Proteus (P. vulgaris, P. mirabilis), Pseudomonas (Ps. aeruginosa, Ps. Fluorescens, Ps. Putida), Klebsiella (K. Ozaenae), Citrobacter (C. freundii) Ta Enterobacter (E. cloacae, E. aerogenes). 3 обробленого дослідним розчином зерна кількість кишкових бактерій була незначною і представлена здебільшого бактеріями кишкової палички та псевдомонадами в незначній кількості $\left(10^{3}\right.$ КУО в 1 г).

\section{Висновки:}

1. Результатами проведених досліджень підтверджено антимікробні властивості комплексного розчину, до складу якого входить «Тебуконазол», мікроелементи срібла та міді у формі органічних солей карбонових кислот, що отримують методами нанотехнологій. Використаний комплексний розчин характеризується проти-

\section{БІБЛІОГРАФІЯ}

1. Барбарош В. Д. Фитопатологическая экспертиза семян / В. Д. Барбарош // Защита и карантин растений. - 2004. - №2. - С. 20-21.

2. Горленко М. В. Болезни пшеницы / М. В. Горленко. - М. : Сельхозиздат, 1971. - С. 75-246. грибковою та бактерицидною дією.

2. Антибактеріальна та фунгіцидна активність найбільш виражена в разі обробки зерна пшениці комплексним розчином зразку зерен, які оброблялись раніше препаратом захисту від шкідників зерна. Це свідчить про те, що, знищуючи комах і кліщів у зерні до його закладки на зберігання, має теж важливе значення, оскільки запобігає інфікуванню зерна за рахунок шкідників.

Перспективи подальших досліджень. Попередити можливі негативні наслідки під час застосування фунгіцидів можна лише за умови здійснення фундаментальних досліджень та розробки на цій основі достовірних прогнозів можливих екологічних ризиків. Така робота $є$ гарантією отримання сільськогосподарської продукції, яка відповідатиме стандартам якості і дасть можливість попереджати негативні процеси в агроекосистемах, пов'язані із застосуванням фунгіцидів.

3. Омельченко В.Д. Зерна, поврежденные и испорченные микроорганизмами и самосогреванием как критерий санитарно-гигиенического состояния пшеницы и кукурузы : автореф. дисс. ... к.т.н. / В. Д. Омельченко. - М., 1991. - С. 1-9. 


\section{СІЛЬСЬКЕ ГОСПОДАРСТВО. РОСЛИННИЦТВО}

4. Левитин М. М. Грибные болезни зерновых культур / М. М. Левитин, С. А. Тютерев // Защита и карантин растений. - 2003. - №11. - С. 76.

5. Химическая защита растений в фитосанитарном оздоровлении агроэкосистем / [Долженко В. И., Новожилов К. В., Сухорученко Г. И., Тютерев С. Л.] // Вестник защиты растений. - 2011. - №3. - С. 3-12.

6. Иващенко В. Г. Фузариоз колоса хлебных злаков / В. Г. Иващенко, Н. П. Шипилова, Л. А. Назаровская. - СПб. : Пушкин ВИЗР, 2004. - 164 с.

7. Назарова Л. Н. Прогрессирующие болезни зерновых культур / Л. Н. Назарова, Е. А. Соколова // Агро XXI. - 2000. - №4. - С. 2-3.

8. Ефективна модифікація фунгіцидного препарату з мікроелементами, отриманими за нанотехнологіями / [Гавриленко О. С., Хоміцька О. А., Пащенко А. Г., Загорулько О. В., Нестерчук Т. В.] // Одеська національна академія харчових технологій. Наукові праці. - 2014. - Вип. 46, Том 1. C. 95-97.

9. Тютерев С. Л. Протравливание семян зерновых колосовых культур / С. Л. Тютерев // Журнал «Защита и карантин растений» (Приложение). - М. : Всероссийский научно-исследовательский институт защиты растений РАСХН. - №3. 2005. - 44 c.

10. Дмитруха Н. М. Оцінка токсичних властивостей нанотехнологічних мікроелементів в дослідах in vivo та in vitro / Н. М. Дмитруха, Т. К. Короленко, О. С. Лагутіна // Тези конференції «Биологически активные вещества и материалы», 2013.

11. ГОСТ 13586.3-2015 Зерно. Правила приемки и методы отбора проб. - М., 2016. - 27 с.

12. ГОСТ 10444.15 - 94 Продукты пищевые. Метод определения мезофильных аэробных и факультативно-анаэробных микроорганизмов. М. : Стандартинформ, 2010.

13. ДСТУ ISO 4833:2006 Мікробіологія харчових продуктів і кормів для тварин. Горизонтальний метод підрахунку мікроорганізмів. Техніка підрахування колоній за температури $25^{\circ} \mathrm{C}$ (ISO 4833:2003, IDT). - [Чинний від 01.10.2007].

14. ГОСТ 26972 - 86 Зерно, крупа, мука для продуктов детского питания. Методы микробиологического анализа. - М., 2003. - 16 с. - [Межгосударственный стандарт].

15. ГОСТ 10444.12-2013 Продукты пищевые. Метод определения дрожжей и плесневых грибов. - М., 2014. - 12 с. - [Межгосударственный стандарт].

16. ДСТУ ISO 7954:2006 Мікробіологія харчових продуктів та кормів для тварин. Загальні настанови з підрахунку дріжджів і мікроскопічних грибів. Техніка підрахування колоній, культивованих за температури $25^{\circ} \mathrm{C}$. - [Чинний від 01.10.2007].

17. ГОСТ 29184 - 91 Продукты пищевые. Методы выявления и определения количества бактерий семейства Enterobacteriaceae. - М., 2010. [Межгосударственный стандарт].

18. ДСТУ 4138-2002 Насіння сільськогосподарських культур. Методи визначення якості. К. : Держстандарт України, 2003. - 173 с.

19. ДСТУ 3768: 2004 Пшениця. Технічні умови. - К. : Держспоживстандарт України, 2004. [Чинний від 28.05.2004].

20. ГОСТ 13496.11-74 Зерно. Метод определения содержания спор головневых грибов. - М., 2009. - 3 с. - [Межгосударственный стандарт].

21. Саттон Д. Определитель патогенных и условно-патогенных грибов / Д. Саттон, А. Фотергилл, М. Ринальди ; [пер. с англ.]. - М. : «Мир», 2001. - 486 с.

22. Литвинов М. А. Определитель микроскопических почвенных грибов / М. А. Литвинов. Л. : Наука, 1967. - 304 с.

23. Елинов Н. П. Краткий микологический словарь (для врачей и биологов). Издание втоpoe, исправленное и дополненное / Н. П. Елинов. СПб. : МГК, 2009. - С. 77-79. 